\title{
Adhesion of Probiotic Bacteria to Resistant Rice Starch
}

\author{
Ghalia Salem, Zaiton Hassan and Maryam Abubakr
}

\author{
Department of Science and Technology, \\ University Sains Islam Malaysia (USIM), Bandar Baru Nilai, 71800 Nilai Negeri Sembilan, Malaysia
}

Received 2012-07-27, Revised 2012-08-26; Accepted 2013-04-25

\begin{abstract}
Resistant starch as prebiotics can be combined with probiotics to increase their survival during processing of food products. In present study Lactic Acid Bacteria (LAB) which, isolated from (yoghurt, banana and human breast milk) were screened for their probiotic properties and evaluated for the adhesion properties to Rice Resistance Starch (RRS). $26 \%$ of the isolates (10/39) overcame the stress to $\mathrm{pH} 3$ and $0.3 \%$ bile indicating their probiotic properties. All ten LAB isolates adhered to RRS within 60 min of exposure. Isolates Bn1 and HM2 were highly adhered to RRS with a total of 79 and $77 \%$ of the cells adhering, respectively. Moderate adherent was observed by isolates FY (55\%), YN (70\%), CY (48\%), HM1 (61, 5\%), HM3 (65\%) and HM4 $(50,5 \%)$, while isolate $\mathrm{YD}$ and $\mathrm{Bn} 2$ were poorly adhered to RRS ( $<40 \%$ adherent). $\mathrm{NaCl}$ and Tween 80 did not influence on adhesion capacity but, the adhesion was inhibited by protease and by low $\mathrm{pH}$. Different effect on adhesion of probiotic bacteria to resistant rice starch was caused by monosaccharides, disaccharides and polysaccharides, depending on their molecular size. The effect of gastric condition (in vitro) appeared, inhibition in adhesion by protease and low $(\mathrm{pH}<3)$. While bile has not affected on adhesion, but the pancreatin caused weakening binding capacity of the starch. It might be possible to utilization adhesion of probiotic and prebiotic in microencapsulation and synbiotic food applications such as bakery products.
\end{abstract}

Keywords: Resistant Starch, Lactic Acid Bacteria, Prebiotic

\section{INTRODUCTION}

Probiotics are live microorganisms that are created food supplements order to promote health for costumers by adjust microbial balance in the intestine (Kosin and Rakshit, 2006). Since a wide circulation of Lactobacillus and Bifidobacteria species in the intestinal tract is generally considered to be signal of a healthy microbiota,they become commonest probiotic bacteria used for a variety of health problems. Loosing probiotic during processing is the most important technological obstacle that must to be solved. Produce large enough amounts of viable and stable probiotic cultures has been technological challenge for industry. Some studies demonstrated that high levels of viable probiotics are recommended in probiotic foods to be functional (Galdeano and Perdigon, 2004).
Prebiotics like resistant starch can be combined with probiotics as synbiotic to make system more resistant to surrounding conditions and more effective (Kosin and Rakshit, 2006). Resistant starch is the starch that can escape from digestion the small intestine by amylases enzyme and arrived to colon where it will be fermented without loosing (Sajilata et al., 2006; Anal and Singh, 2007). This system provides protective device of probiotics is reliable in media simulating the gastric fluid and then probiotics are released in the large intestine. while, resistant starch can be used by probiotics in the large intestine as energy source (Mortazavian et al., 2008).

Adhesion of different species of probiotics such as Bifidobacterium spp to native maize, oat, potato and barley starch granule showed that are not all the Bifidobacteria strains have adhesive characteristic to

Corresponding Author: Ghalia Salem, Department of Science and Technology, University Sains Islam Malaysia (USIM), Bandar Baru Nilai, 71800 Nilai Negeri Sembilan, Malaysia 
starch granules (Crittenden et al., 2001) furthermore, the researchers are not sure about if there are any effect by adhesion in starch metabolism by probiotic. The present work studied the ability of LAB isolated from different sources with potential probiotic properties to adhere to several resistant rice starch granules, to achieve a preliminary comprehension of the adhesion mechanisms.

Probiotic adhesion to starch may add advantages in new probiotic technologies through protection these probiotics during processing and storage, also to target the release of the bioactive to large intestinal tract. The researchers lately developed microencapsulation technology by addition of Prebiotic compounds, such as starch to promotes the survival of Probiotic bacteria. This technique is used to ensure protection probiotic bacteria from untoward environmental conditions where they may not normally survive. Thus, other aim of this study was to estimate The possibility of utilization from adhesion of probiotic and prebiotic in microencapsulation and synbiotic food applications such as bakery products.

\section{MATERIALS AND METHODS}

\subsection{Starch Isolation from Rice}

According to Wang and Wang (2001) method,100 g rice flour was soaked in $200 \mathrm{~mL} \mathrm{NaOH}$ at concentration of $0.1 \%$ for $18 \mathrm{~h}$. The slurry was mixed robustly by a blender (BERJAYA 1/BSP-CB2L) for $2 \mathrm{~min}$. then passing the slurry through screen $(63 \mu \mathrm{m})$ and centrifuged at $1400 \times \mathrm{g}$ for $10 \mathrm{~min}$. The residue was washed with $0.1 \% \mathrm{NaOH}$ and water, then $\mathrm{PH}$ was adjusted to $\mathrm{pH} 6.5$ by $\mathrm{Hcl}(1.0 \mathrm{~N})$, then centrifuged again . lastly The starch was washed three times by deionized water then dried at an oven $\left(45^{\circ} \mathrm{C}, 48 \mathrm{~h}\right)$.

\subsection{Resistant Rice Starch (RRS) Formation}

Resistant rice starch was prepared following the method of Pongjanta et al. (2008), as every $15 \mathrm{~g}$ of rice starch was mixed with $100 \mathrm{~mL}$ of distilled water $(15 \% \mathrm{w} / \mathrm{v})$. The mixtures were kept at $30^{\circ} \mathrm{C}$ for $1 \mathrm{~h}$ with subjected them to strong shake by occasional vigorous shaking.Then samples were heated to approximately $75^{\circ} \mathrm{C}$ for $30 \mathrm{~min}$. The gelatinized samples were cooled to $55^{\circ} \mathrm{C}$, which was ideal temperature for pullulanase enzyme. 8 unit pullulanase enzymes per gram starch were added at $55^{\circ} \mathrm{C}$ for $48 \mathrm{~h}$ in water bath. When the enzyme treatments were completed, the samples were autoclaved at $121^{\circ} \mathrm{C}$ for $15 \mathrm{~min}$. The samples were incubated at $4^{\circ} \mathrm{C}$ for $16 \mathrm{~h}$ then subjected to one cycle of freezing and thawing process $\left(-10 / 30^{\circ} \mathrm{C}\right)$. The resistant starch was collected and dried at an oven $\left(45^{\circ} \mathrm{C}\right)$. Then the samples were milled and sieved through a 100- mesh sieve and packaging away from moisture at room temperature for further determinations.

\subsection{Isolation of Lactic Acid Bacteria from Different Sources}

\subsubsection{Yoghurt and Fermented Banana}

Locally available fermented dairy products, namely: Yoghurt Natural (YN), Children Yoghurt (CY), Yoghurt Drink (YD), Fruit Yoghurt (FY) and Fermented banana, which all claimed to contain Lactic Acid Bacteria (LAB), was used in this study as sources of LAB. Three (3) samples of each product were bought from the several supermarkets were obtained. About $10 \mathrm{~g}$ of sample was added to $90 \mathrm{~mL} 0.1 \%$ peptone water and appropriate dilution was spread plated on de Man, Rogosa and Sharpe (MRS) agar (Oxoid CM0361) plates containing $0.8 \%$ calcium carbonate $\left(\mathrm{CaCO}_{3}\right)$. Plates were incubated anaerobically (in anaerobe jar using Oxoidanaerogen compact) at $37^{\circ} \mathrm{C}$ for $48 \mathrm{~h}$. The bacterial strains were kept at $-20^{\circ} \mathrm{C}$ after adding $15 \%$ glycerol stock. Each bacterial strain was sub-cultured at least three times $(1 \%, \mathrm{v} / \mathrm{v})$ at $24 \mathrm{~h}$ befor using in subsequent study (Kheadr, 2006).

\subsection{Human Breast Milk}

The samples were collected sterilely from 10 mothers were in a good health then delivered to the laboratory on ice. Samples were diluted to $10^{-1}, 10^{-2}$ and $10^{-3}$ using sterile peptone water, then $1 \mathrm{ml}$ of each sample were poured into MRS-cystein agar $(\mathrm{pH} \mathrm{5.5)}$. The plates were incubated Anaerobically at $37^{\circ} \mathrm{C}$ for 3 days (Yavuzdurmaz, 2007).

\subsection{Probiotic Properties of Isolates}

\subsubsection{Oxbile Tolerance}

The tolerance of LAB strains to oxbile was evaluated by fowlloing Kheadr (2006) method. The mixture of MRS broth (Oxoid CM0359) with $0.3 \% \mathrm{w} / \mathrm{v}$ oxbile was prepared then filled each well of sterile flatbottom 96-well microtiter plate (Falcon, Becton Dickinson and Company, Frankin Lakes, NJ, USA) by $150 \mu \mathrm{L}$ and $30 \mu \mathrm{L}$ of the overnight culture which diluted to $1 / 1000$ in the same broth. Then incubated the Microplate at $37^{\circ} \mathrm{C}$ for $24 \mathrm{~h}$ under anaerobic conditions. A biophotometer (Eppendorf Asia Pacific Sdn. Bhd) at $600 \mathrm{~nm}$ was used to measured the optical densities.

\subsection{Acid Challenge}

Ten $\mathrm{mL}$ of cultures which incubation with MRS until reached mid-log-phase were obtained by centrifugation at $6,000 \times \mathrm{g}$ for $15 \mathrm{~min}$ at $4^{\circ} \mathrm{C}$ (AllaegraTM 25R centrifuge, Beckman Coulter TM), then resuspended in the same volume of MRS broth (Oxoid CM0359) at $\mathrm{pH} 2.0$. Then incubated the suspantion at $37^{\circ} \mathrm{C}$ for $60 \mathrm{~min}$ under anaerobic conditions. 
Table 1. Treatments used in the investigation of mechanisms of adhesion

\begin{tabular}{|c|c|}
\hline Treatment & Description \\
\hline Phosphate buffer & The adhesion experiment was performed in $0.1 \mathrm{M}$ phosphate buffer $(\mathrm{pH} 7.0)$ \\
\hline Fresh medium & The adhesion experiment was performed in fresh growth medium ( $\mathrm{pH} 6.8$ ) \\
\hline Spent medium & $\begin{array}{l}\text { The adhesion experiment was performed in spent supernatant from a } 24-\mathrm{h} \\
\text { culture of the bacterial strain }(\mathrm{pH} 4.5)\end{array}$ \\
\hline Pepsin-treated spent medium & $\begin{array}{l}\text { The adhesion experiment was performed in spent medium treated with } 30 \\
\mathrm{U} \text { of pepsin } \mathrm{A} \text { (EC } 3.4 .23 .1 \text {; Sigma Chemical Co., St. Louis, Mo.) } \mathrm{m} \mathrm{L}^{-1} \text { for } \\
6 \mathrm{~h} \text { at } 37^{\circ} \mathrm{C} \text {; for pepsin treatment, the pH of the medium was reduced to } 2.0 \text { by } \\
\text { using } 0.1 \mathrm{M} \mathrm{HCl} \text { and then readjusted prior to the adhesion experiment to } 4.5 \text { by } \\
\text { using } 0.1 \mathrm{M} \mathrm{NaOH}\end{array}$ \\
\hline Pepsin-treated starch & $\begin{array}{l}\text { The adhesion experiment was performed by using RRS that had been treated with } 30 \\
\mathrm{U} \text { of pepsin } \mathrm{m} \mathrm{L}^{-1}\left(\text { at } \mathrm{pH} 2.0 \text { ) for } 6 \mathrm{~h} \text { at } 37^{\circ} \mathrm{C} \text {; RRS was washed and resuspended in }\right. \\
\text { phosphate buffer ( } \mathrm{pH} 7.0 \text { ) for the adhesion experiment }\end{array}$ \\
\hline ProteinaseK-treated cells & $\begin{array}{l}\text { Cells }\left(10^{8} \mathrm{CFU} \mathrm{m} \mathrm{L}{ }^{-1}\right) \text { were pretreated with } 10 \mathrm{U} \text { of proteinase } \mathrm{K} \text { (Roche Molecular } \\
\text { Biochemicals, Basel, Switzerland) } \mathrm{mL}^{-1} \text { at } \mathrm{pH} \\
7.0 \text { for } 6 \mathrm{~h} \text { at } 37^{\circ} \mathrm{C} \text {; the cells were then washed twice and the adhesion experiment } \\
\text { was performed in } 0.1 \mathrm{M} \text { phosphate buffer }(\mathrm{pH} 7.0)\end{array}$ \\
\hline $\mathrm{NaCl}$ & $\begin{array}{l}\text { The adhesion experiment was performed in } 0.1 \mathrm{M} \text { phosphate buffer } \\
(\mathrm{pH} 7.0 \text { ) containing } 0.5 \mathrm{M} \mathrm{NaCl}\end{array}$ \\
\hline Tween 80 & $\begin{array}{l}\text { The adhesion experiment was performed in } 0.1 \mathrm{M} \text { phosphate buffer } \\
\text { (pH 7.0) containing } 3.0 \mathrm{~g} \text { of Tween } 80 \mathrm{~L}^{-1}\end{array}$ \\
\hline Pepsin-treated cells & $\begin{array}{l}\text { Cells }\left(10^{8} \mathrm{CFU} \mathrm{m} \mathrm{L} \mathrm{L}^{-1}\right) \text { were pretreated with } 30 \mathrm{U} \text { of pepsin } \mathrm{m} \mathrm{L}^{-1} \text { at } \mathrm{pH} 2.0 \\
\text { for } 6 \mathrm{~h} \text { at } 30^{\circ} \mathrm{C} \text {; the cells were then washed twice and the adhesion } \\
\text { experiment was performed in } 0.1 \mathrm{M} \text { phosphate buffer }(\mathrm{pH} 7.0)\end{array}$ \\
\hline Effect of potential inhibitors & $\begin{array}{l}\text { The adhesion experiment was performed in } 0.1 \mathrm{~m} \text { phosphate } \\
\text { buffer ( } \mathrm{pH} \text { 7.0) containing } 5 \mathrm{~g} \text { of one of the following carbohydrates per liter: } \\
\text { glucose, maltose, lactose, sucrose, maltodextrin and amylose }\end{array}$ \\
\hline
\end{tabular}

Source: Crittenden et al. (2001)

To determination viability of bacteria before and after incubation $10 \mathrm{~g}$ of sample was added to $90 \mathrm{~mL} 0.1 \%$ peptone water and appropriate dilution was spread plated on de Man, Rogosa and Sharpe (MRS) agar. Plates then incubated anaerobically at $37^{\circ} \mathrm{C}$ for $48 \mathrm{~h}$ (Kheadr, 2006).

\subsection{Oxbile Challenge}

Ten $\mathrm{mL}$ of cultures which incubation with MRS until reached mid-log-phase were obtained by centrifugation at $6,000 \times \mathrm{g}$ for $15 \mathrm{~min}$ at $4^{\circ} \mathrm{C}$, then resuspended in the same volume of MRS broth at $\mathrm{pH} 6.5$ containing $0.3 \%(\mathrm{w} / \mathrm{v})$ oxbile. Then incubated the suspantion at $37^{\circ} \mathrm{C}$ for $90 \mathrm{~min}$ under anaerobic conditions.

To determination viability of bacteria before and after incubation $10 \mathrm{~g}$ of sample was added to $90 \mathrm{~mL}$ $0.1 \%$ peptone water and appropriate dilution was spread plated on (MRS) agar. Plates were incubated anaerobically at $37^{\circ} \mathrm{C}$ for $48 \mathrm{~h}$ (Kheadr, 2006).

\subsection{Determination of Adhesion Level by a Co- Sedimentation Assay}

Determination of adhesion level by co-sedimentation assay followed the method of Crittenden et al. (2001). The cells were washed twice with $10 \mathrm{ml}$ of $0.1 \mathrm{M}$ phosphate buffer ( $\mathrm{pH} 7.0)$, then they are suspended in the same buffer (concentration $=10^{7}$ cells $\mathrm{mL}^{-1}$ ). In a $1-\mathrm{cm}$ diameter test tube two milliliters of the bacterial suspension were mixed with an equal volume of a suspension of starch granules $\left(10 \mathrm{~g} \mathrm{~L}^{-1}\right)$ in $0.1 \mathrm{M}$ phosphate buffer $(\mathrm{pH} 7.0)$. The suspension was let for $1 \mathrm{~h}$ at room temperature to allow the starch to sediment. Two $1.5 \mathrm{~mL}$ samples were then taken from $0.5 \mathrm{~cm}$ below the liquid surface and by a spectrophotometer the optical density was measured (at 540 $\mathrm{nm})$. Then find the result as follows:

Percentage of cells adhering to starch $=\mathrm{a}-\mathrm{b} / \mathrm{c}$

$\mathrm{a}=$ OD540 of a sample containing starch plus bacteria $\mathrm{b}=$ OD540 of a sample containing starch but no bacteria $\mathrm{c}=$ OD540 of a sample containing bacteria but no starch

Highly adherent (more than $70 \%$ of the cells adhered to the starch) as (40-70\% adhesion) were named as moderate however less than $40 \%$ adhesion were named as poor adherent strains. 
Table 2. Treatments used to simulate conditions for adhesion during passage through the upper gastrointestinal tract

\begin{tabular}{|c|c|}
\hline Treatment & Description \\
\hline Effect of $\mathrm{pH}$ & $\begin{array}{l}\text { The adhesion experiments were performed in } 0.1 \mathrm{M} \text { citrate-phosphate } \\
\text { buffers at } \mathrm{pH} 2.0,3.0,4.0,5.0,6.0,7.0 \text { and } 8.0\end{array}$ \\
\hline Effect of acid plus pepsin & $\begin{array}{l}\text { The adhesion experiments were performed in } 0.2 \mathrm{M} \mathrm{HCl}-\mathrm{KCl} \text { buffer } \\
\text { (pH 3.0) containing }\end{array}$ \\
\hline & $30 \mathrm{U}$ of pepsin A (EC 3.4.23.1; (Sigma Chemical Co.) m L ${ }^{-1}$ \\
\hline Effect of bile & $\begin{array}{l}\text { The adhesion experiments were performed in } 0.1 \mathrm{M} \text { phosphate buffer } \\
\text { (pH 7.0) containing } 3.0 \mathrm{~g} \text { of bile (Sigma Chemical Co.) } \mathrm{L}^{-1}\end{array}$ \\
\hline Effect of pancreatic & $\begin{array}{l}\mathrm{RRS} \text { was pretreated for } 6 \mathrm{~h} \text { at } 37^{\circ} \mathrm{C} \text { with } 0.01 \mathrm{~g} \text { of pancreatic } \\
\text { (Sigma Chemical Co.) } \mathrm{g}^{-1} \text {; the RRS was washed twice and the } \\
\text { adhesion experiments were performed in } 0.1 \mathrm{M} \text { phosphate buffer }(\mathrm{pH} 7.0)\end{array}$ \\
\hline
\end{tabular}

Source: Crittenden et al. (2001)

\subsection{Study of Adhesion Mechanisms}

Studies of the mechanisms of adhesion were aimed to determine whether adhesion was due to the growth medium components, hydrophobic or electrostatic interactions, or specific cellular or extracellular proteins produced by the bacteria. In addition, to determined nature of the receptor sites in the adhesion reaction, study the effect of some inhibitors of adhesion inclusive: glucose, maltose, sucrose, lactose, amylose and maltodextrin was done. The treatments used in the adhesion assay are described in (Table 1). The experiments were performed with two adherent strains $\mathrm{Bn} 1$ and $\mathrm{Hm} 2$. Each experiment was performed three times. The bacteria were in the stationary phase when they were used in the adhesion assay. For each assay, 2 $\mathrm{mL}$ of bacterial suspension were mixed with same volume of starch $\left(10 \mathrm{~g} \mathrm{~L}^{-1}\right)$ suspended in the appropriate treatment medium (phosphate buffer, fresh medium).

\subsection{Adhesion Under Conditions that Simulated the Upper Gastrointestinal Tract Conditions}

To determine the effect of some of the conditions of the stomach and small intestine on bacterial adhesion to RRS, adhesion experiments were performed in vitro under conditions simulating the physiological conditions in the upper gastrointestinal tract (Table 2).

\subsection{Statistical Analysis}

The results are presented as mean \pm standard deviations of three replicate determinations and were statistically analyzed by two-way Analysis of Variance (ANOVA) at $(\mathrm{p} \leq 0.05)$.

\section{RESULTS}

\subsection{Isolation of $L A B$}

About 39 bacteria were isolated from different sources. From those isolates 18 showed clear zone on modified MRS- $\mathrm{CaCO}_{3}$ agar, catalase test negative and Gram positive and were considered as LAB (Table 3).

\subsection{Probiotic Properties of Isolates}

\subsubsection{Oxbile Tolerance}

Previous studies proved That bile concentration of the human gastro intestinal tract is $0.3 \% \mathrm{w} / \mathrm{v}$. Growth was monitored at OD600, it was observed that all ten isolates showed varied degree of growth when grown on MRS medium supplemented with concentration ( $0.3 \%)$ of bile salt. From Table 4, it was observed that HM2 showed the highest value of OD600 (1.23) while Bn2 showed the lowest absorbance (0.689). Other isolates were in the range of 0.711 to 1.092 .

\subsection{Acid and Oxbile Challenge}

Survival of isolates after acid and oxbile stresses is shown in (Table 5). Showed viable counts $\left(\log ^{10}\right.$ $\mathrm{cfu} / \mathrm{mL}$ ) of probiotic isolates at the beginning and end of acid and oxbile stress and percentage survival of the isolated strains in the acid and oxbile stress (Table 6). All ten isolates could survive and increased viability in acidic condition by 0.01 to $0.35 \log ^{10}$ $\mathrm{cfu} / \mathrm{mL}$.

\subsection{Determination of Adhesion Level by a Co- Sedimentation Assay}

Ten species of bacteria adhered to rice starch granules with in $60 \mathrm{~min}$ of exposure to the granules (Fig. 1). Bn1 and HM2 adhered well to rice starch with a total of 79 and $77 \%$ of the cells adhering (highly adherent). $\mathrm{YN}=70, \mathrm{CY}=48, \mathrm{FY}=55, \mathrm{HM} 1=61,5, \mathrm{HM} 3=65$ and HM4 $=50,5 \%$ species adhered less well (moderate adherent). $\mathrm{YD}=20$ and $\mathrm{Bn} 2=18 \%$ species adhered less than $40 \%$ (Poorly adherent). 
Table 3. Phenotypic characteristics of $\mathrm{LAB}$ isolated

\begin{tabular}{|c|c|c|c|c|c|c|c|}
\hline No. & Source & Code & $\mathrm{CaCO}_{3}{ }^{\mathrm{a}}$ & Catalase reaction & Gram reaction & Gas from glucose & Cell morphology \\
\hline \multirow[t]{3}{*}{1} & \multirow[t]{3}{*}{ Yoghurt natural } & YN1 & + & - & + & - & Rod \\
\hline & & YN2 & + & - & + & + & Coccid \\
\hline & & YN3 & + & - & + & + & Coccid \\
\hline 2 & Children yoghurt & $\mathrm{CY}$ & + & - & + & - & Rod \\
\hline \multirow{2}{*}{3} & \multirow{2}{*}{ Yoghurt drink } & YD1 & + & - & + & - & Short rod \\
\hline & & YD2 & + & - & + & + & Rod \\
\hline \multirow[t]{2}{*}{4} & \multirow[t]{2}{*}{ Fruit yoghurt } & FY1 & + & - & + & - & Rod \\
\hline & & FY2 & + & - & + & & Rod \\
\hline \multirow[t]{5}{*}{5} & \multirow[t]{5}{*}{ Banana } & Bn1 & + & - & + & - & Short rod \\
\hline & & $\mathrm{Bn} 2$ & + & - & + & - & Rod \\
\hline & & $\mathrm{Bn} 3$ & + & - & + & + & Coccid \\
\hline & & $\mathrm{Bn} 4$ & + & - & + & + & Coccid \\
\hline & & Bn5 & + & - & + & + & Rod \\
\hline \multirow[t]{5}{*}{6} & \multirow[t]{5}{*}{ Human milk } & HM1 & + & - & + & + & Short rod \\
\hline & & HM2 & + & - & + & + & Short rod \\
\hline & & HM3 & + & - & + & + & Rod \\
\hline & & HM4 & + & - & + & + & Rod \\
\hline & & HM5 & + & - & + & - & Coccid \\
\hline
\end{tabular}

$(+)$ positive, (-) negative

Table 4. Growth of LAB in $0.3 \%$ oxbile $^{\mathrm{a}}$

\begin{tabular}{ll}
\hline Isolates & OD600 \\
\hline YN 0.961 & \\
CY 0.711 & \\
YD 1.092 & \\
FY 0.933 & \\
Bn1 1.004 & \\
Bn2 0.689 & \\
HM1 & 0.777 \\
HM2 & 1.230 \\
HM3 & 0.867 \\
HM4 & 0.822
\end{tabular}

A Titer plates were incubated at $37^{\circ} \mathrm{C}$ for $24 \mathrm{~h}$ anaerobically and growth was monitored at OD600 nm

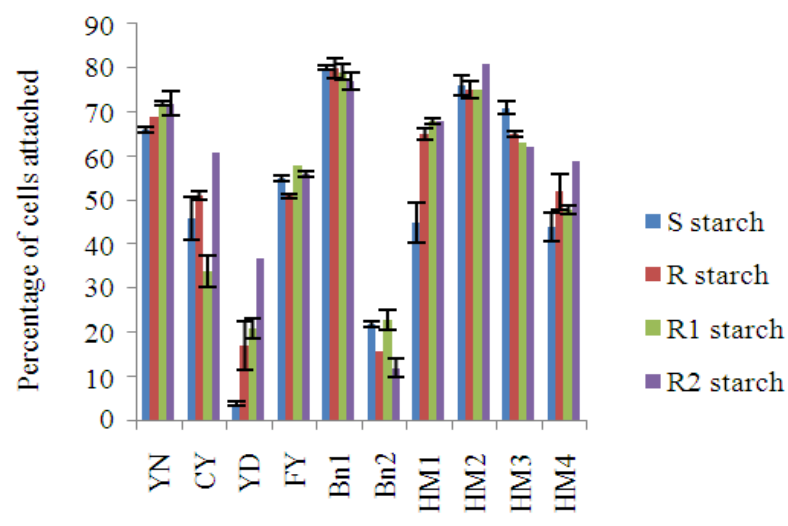

Lactic acid bacteria

Fig. 1. Percentage of cells adhering to resistant rice starch $(\mathrm{S}=$ soluble starch, $\mathrm{R}=$ white rice starch, $\mathrm{R} 1=$ unpolished brown rice starch, $\mathrm{R} 2$ = grow Cambodian brown rice starch). Error bars indicate \pm 1 standard deviation from the mean $(n=3)$
Table 5. Viable counts $(\log 10 \mathrm{cfu} / \mathrm{mL})$ of LAB isolates at the beginning and end of acid and oxbile stress experiments

\begin{tabular}{lllll}
\hline & \multicolumn{3}{l}{ Acid stress $^{\mathrm{a}}$} & \multicolumn{2}{l}{ Oxbile stress $^{\mathrm{b}}$} \\
\hline Isolates & 0 min & $60 \mathrm{~min}$ & $0 \mathrm{~min}$ & $60 \mathrm{~min}$ \\
\hline YN & $9.08 \pm 0.06$ & $9.11 \pm 0.03$ & $9.29 \pm 0.03$ & $9.34 \pm 0.01$ \\
CY & $8.26 \pm 0.15$ & $8.29 \pm 0.25$ & $8.81 \pm 0.21$ & $9.17 \pm 0.08$ \\
YD & $8.98 \pm 0.05$ & $9.23 \pm 0.16$ & $9.18 \pm 0.09$ & $9.27 \pm 0.03$ \\
FY & $8.55 \pm 0.08$ & $8.56 \pm 0.10$ & $8.84 \pm 0.01$ & $9.11 \pm 0.06$ \\
Bn1 & $9.12 \pm 0.00$ & $9.31 \pm 0.06$ & $9.00 \pm 0.00$ & $9.17 \pm 0.03$ \\
Bn2 & $7.00 \pm 0.29$ & $7.35 \pm 0.00$ & $7.03 \pm 0.00$ & $7.47 \pm 0.19$ \\
HM1 & $7.60 \pm 0.46$ & $7.69 \pm 0.46$ & $7.40 \pm 0.32$ & $8.26 \pm 0.15$ \\
HM2 & $9.70 \pm 0.02$ & $9.92 \pm 0.02$ & $8.77 \pm 0.04$ & $9.37 \pm 0.05$ \\
HM3 & $8.90 \pm 0.19$ & $8.98 \pm 0.09$ & $9.00 \pm 0.26$ & $9.33 \pm 0.06$ \\
HM4 & $7.11 \pm 0.26$ & $7.20 \pm 0.46$ & $8.34 \pm 0.28$ & $8.37 \pm 0.23$ \\
\hline
\end{tabular}

(a) Cells kept for $60 \mathrm{~min}$ in MRS broth adjusted to $\mathrm{pH} 2.0$ at $37^{\circ} \mathrm{C}$ (b) Cells exposed to $0.3 \%(\mathrm{w} / \mathrm{v})$ oxbile in MRS broth at pH 6.5 at $37^{\circ} \mathrm{C}$

Table 6. Percentage survival of the LAB isolates strains in the acid and oxbile stress

\begin{tabular}{lcr}
\hline & Survival (\%) & \\
Isolates & - & Acid stress \\
\hline YN & 3 & Acid stress $^{\mathrm{a}}$ \\
CY & 3 & 36 \\
YD & 25 & 9 \\
FY & 1 & 27 \\
Bn1 & 9 & 17 \\
Bn2 & 35 & 44 \\
HM1 & 9 & 86 \\
HM2 & 22 & 60 \\
HM3 & 8 & 33 \\
HM4 & 9 & 3 \\
\hline
\end{tabular}




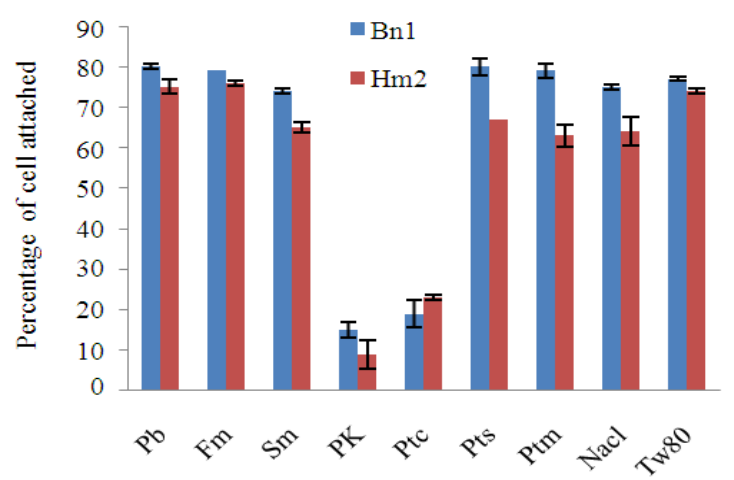

Fig. 2. The effect of chemicals $(\mathrm{NaCl}$, Twe 80 Tween 80 and Pho phosphate buffer), pepsin and proteinase (pts pepsin-treated starch, ptc pepsin-treated cells, pk protenase-K-treated cells) on the attachment of probioticsto resistant rice starch. Error bars indicate \pm 1 standard deviation from the mean $(\mathrm{n}=3)$

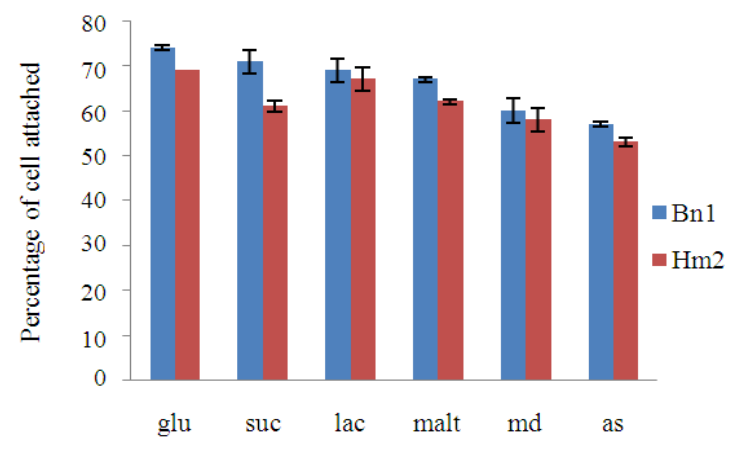

Fig. 3. The effect of monosaccharides (glu glucose) disaccharides (suc sucrose, lac lactose, malt maltose) polysaccharides (md maltodextrin, as amylose) on the adhesion of probiotics to resistant rice starch. Error bars indicate \pm 1 standard deviation from the mean $(\mathrm{n}=3)$

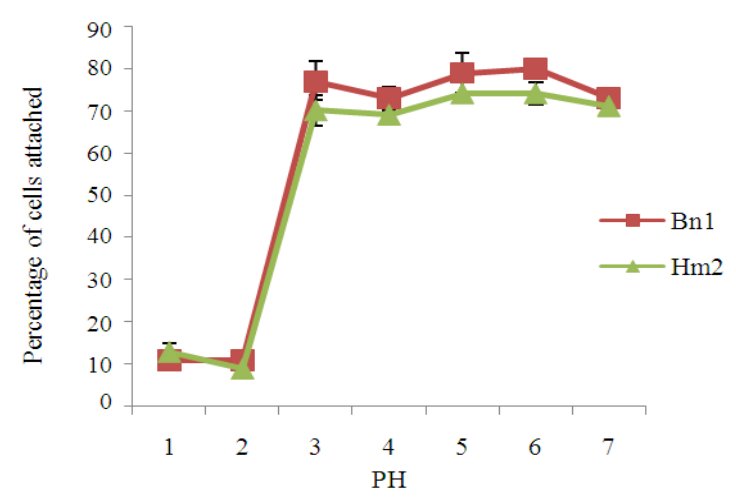

Fig. 4. Effect of $\mathrm{pH}$ on adhesion of $\mathrm{Bn} 1$ and $\mathrm{HM} 2$ to resistant rice starch. Error bars indicate \pm 1 standard deviation from the mean $(n=3)$

\subsection{Adhesion Mechanisms}

Assessment the contributions of a group of possible adhesion mechanisms to adhesion of probiotic bacteria to resistant rice starch were done as mention at (Table 1). Several growth media were used to test their effects on adhesion. Adhesion factors in fresh or spent extracellular medium did not play a role in adhesion, since washing the cells and resuspending them in buffer, fresh medium, or pepsin-treated spent medium did not inhibit adhesion (Fig. 2).

The effect of hydrophobic interactions was studied by addition of Tween 80 which, did not inhibit adhesion. As did adding $0.5 \mathrm{M} \mathrm{NaCl}$ to similarly reduce electrostatic interactions between the starch and the bacteria also failed to inhibit adhesion (Fig. 2).

The role of bacterial proteins in adhesion was studied by using proteolytic and chemical treatments aimed at reducing adhesion. Pretreatment of Bn1and $\mathrm{Hm} 2$ bacteria with pepsin at $\mathrm{pH} 2.0$ completely inhibited adhesion to the starch. To determine if the reduction in adhesion observed after treatment of the cells with pepsin at $\mathrm{pH} 2.0$ was due to protease activity or simply to low $\mathrm{pH}$, the cells were also treated with proteinase $\mathrm{K}$ at $\mathrm{pH}$ 7.0. This treatment also resulted in a significant reduction in the level of adhesion $\mathrm{Bn} 1$ and $\mathrm{Hm} 2$ to RRS to 13 and 9\% Respectively (Fig. 2). However, treatment of the starch with the protease (pepsin) did not significantly reduce adhesion (Fig. 2), suggesting that the cells were not adhering to any proteins or peptides associated with the starch granules.

The effect of monosaccharides, disaccharides and polysaccharides on bacterial adhesion to rice starch is variable, with the degree of inhibition increasing with molecular size. Adhesion was not inhibited clearly by glucose, sucrose, lactose, or maltose. However, both amylose and amylopectin inhibited adhesion to approximately the same extent (Fig. 3).

\subsection{Adhesion under Simulated Upper Digestive Conditions}

The influence of digestive tract conditions on bacterial adhesion to rice starch was examined. At $\mathrm{pH}$ more than 4.0 (Fig. 4) and presence of bile (Fig. 5) have not affected on adhesion, while $\mathrm{pH}$ from 2.0 to 3.0 and protease showed a clear effect on adhesion, so the adhesion will not be preserved during the passage through the stomach. Moreover, treatment of the starch granules with pancreatin led to reduced adhesion capacity (Fig. 5). 


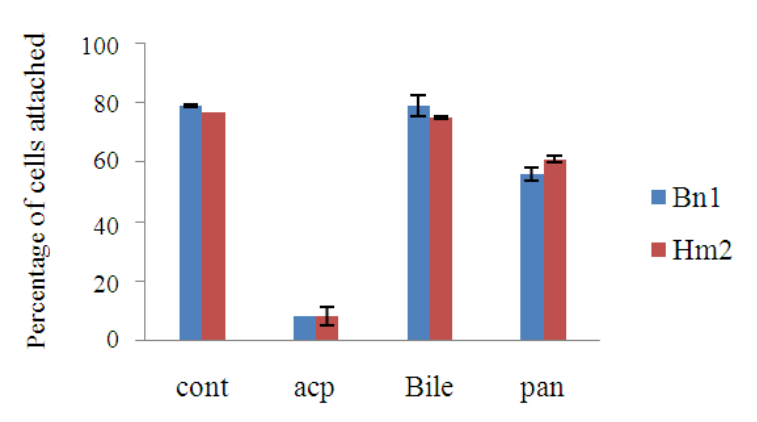

Fig. 5. Influence of upper gastrointestinal conditions (acp acid plus pepsin, bile, pan pancreatic) on adhesion of $\mathrm{Bn} 1$ and HM2 to resistant rice starch Error bars indicate \pm 1 standard deviation from the mean $(\mathrm{n}=3)$

\section{DISCUSSION}

Using probiotics as health supplements became widespread, since substitution the use of chemical supplements or antibiotic growth promoters in animals by probiotics (Kosin and Rakshit, 2006). Oral administration of Lactobacillus and Bifidobacterium is able to adjusting microbial balance in the intestine (Shah, 2006). Loosing probiotic during processing is the most important technological obstacle that must to be solved. Produce large enough amounts of viable and stable probiotic cultures has been technological challenge for industry. Some studies demonstrated that high levels of viable probiotics are recommended in probiotic foods to be functional (Galdeano and Perdigon, 2004).

Prebiotics like resistant starch can be arrived to the colon with out digestion during passage through the human small intestine (Cummings and Macfarlane, 1997). Resistant starch has a suitable surface for adherence of the probiotics to the starch granule during processing, storage and transit through the upper regions of the gastrointestinal tract (Crittenden et al., 2001).

It was reported that adhesion of different species of probiotics such as Bifidobacterium spp to native maize, potato, oat and barley starch granule showed that starch adhesion was not characteristic of all the Bifidobacteria tested (Crittenden et al., 2001). Our finding indicated that probiotic bacteria isolated from the various source showed different adhesion level to resistant starch extracted from three type of rice using a cosedimentation assay. Ten species of bacteria adhered to rice starch granules within $60 \mathrm{~min}$ of exposure to the granules. Bn1 and HM2 adhered well to rice starch with a total of 79 and $77 \%$ of the cells adhering (highly adherent). $\mathrm{YN}=70, \mathrm{CY}=48, \mathrm{FY}=55, \mathrm{HM} 1=61,5$, HM3 $=65$ and HM4 $=50,5 \%$ species adhered less well (moderate adherent). YD $=20 \%$ and $\mathrm{Bn} 2=18 \%$ species adhered less than $40 \%$ (Poorly adherent), adhesion to starch granules was measured by a co sedimentation assay.

There is no any effect by extracellular proteins in the adhesion, this fact appeared clearly when treating the spent growth medium with pepsin did not change in values of adhesion of probiotic to rice resistant starch (Fig. 2). Extracellular components have been played an important role in the adhesion of Lactobacillus fermentum and L. acidophilus to human intestinal cells (Conway and Kjelleberg, 1989; Coconnier et al., 1992).

In this study did not notice any effective difference in values of adhesion of probiotics which already have treated with Tween 80 to rice resistant starch (Fig. 2), that agreed with previous work by Fernando et al. (2011) which; studied attachment of Bifidobacteria and Lactobacilli to rice fiber fractions. Hwang et al. (2008) have Indicated in their study that adding Tween 80 can increase portability of bacterial adhesion to fiber in animal feed. While the results showed decrease portability of bacterial adhesion to fiber in animal feed in the previous study by (Lee et al., 2007). Tween 80 is one of the important food additives (Hwang et al., 2008).

Addition of $0.5 \mathrm{M} \mathrm{NaCl}$ did not affect adhesion of probiotic to rice resistant starch (Fig. 2), that agreed with previous work by Crittenden et al. (2001). while another study performed by (Niderman-Meyer et al., 2009) showed, reduction in adhesion of vibrio cholerae to granular starch by adding $0.5 \mathrm{M} \mathrm{NaCl}$.

Primarily responsible for adhesion of probiotic bacteria to starch granules is cell surface proteins or glycoproteins belong to bacteria not to starch. where the treatment of the resistant starch with the protease did not cause a significant reduction in adhesion $(p<0.05)$ (Fig. 2) however, treatment of bacteria with pepsin and pancreases caused a significant reduction. This is agreed with two studies which have conducted by (Bernet et al., 1993; Imam and Harry-O'Kuru, 1991; Chauviere et al., 1992). There is a different effect of saccharides on adhesion of probiotic to rice resistant starch (Fig. 3). Polysaccharides inhibited adhesion compared with monosaccharides and disaccharides (Fig. 3). This indicates that adhesive proteins have a stronger affinity for larger molecular size of starch polymer chains. Our finding have had agreed strongly with results of Imam and Harry-O'Kuru (1991) who studied the adhesion of Lactobacillus amylovorus with corn starch.

The influencing of the digestive conditions on adhesion of probiotic bacterial to rice starch was studied by a set of tests. Medium $\mathrm{pH}$ was first factor that has been studied and results showed that neither probiotic bacteria nor resistant rice starch granules are affected by pH (Fig. 4). This accorded with previous studies which were showed that a $\mathrm{pH}>4.0$ do not affect on the adhesion 
of Bifidobacteria to Hylon VII starch (Crittenden et al., 2001) or on adherence of V. alginolyticus to chitin (Pruzzo et al., 1996). So $\mathrm{pH}$ gradient in the Upper digestive tract does not constitute an obstacle to bacterial adhesion with starch granules.

One beneficial effect that has been resulted from probiotics is a reduction in serum cholesterol levels, due to an enzymatic deconjugation of bile acids (Topping, 1991; Corzo and Gilliland, 1999). On the other hand, deconjugated free bile salt inhibits probiotics. Previous studies have noted that presence of resistant starch promoted survival of Bifidobacteria in the intestinal tract of rats even though, in the presence of bile and low pH (Wang et al., 1999). Although present study showed that bile did not influence bacterial adhesion to rice starch. While, treatment of the starch granules with pancreatin has reduced the ability of interdependence between the starch and bacteria. Also the study have done by (Niderman-Meyer et al., 2009) found that treatment of the starch granules with pancreatin has reduced the ability of binding of Hylon VII starch granules and Bifidobacterium strains.

Adhesion to resistant starch can be considered as a better methods to increase Probability of survival of probiotic bacteria through the digestive tract.

\section{CONCLUSION}

The present study focused on ability of LAB isolated from different sources with potential probiotic properties to adhere to several resistant rice starch granules, to achieve a preliminary comprehension of the adhesion mechanisms. The adhesion level was measured by a co-sedimentation assay. In addition, this study had been shown that probiotic isolates have different level of attachment to several type of resistant rice starch. The adhesion of probiotic bacteria to starch appeared as a result of presence of a specific cell surface protein(s) instead of nonspecific hydrophobic or electrostatic interactions. In an vitro gastric model, adhesion to starch may not be influenced by bile but, adhesion was inhibited both by the action of protease and at $\mathrm{pH}$ values of $<3$ (the binding capacity was reduced by low $\mathrm{pH}$ and acid pepsin solutions).

One of the solutions to ensure adhesion of probiotic bacteria to resistant starch during passage through the gastrointestinal tract is microencapsulation, so it may be possible to exploit adhesion of probiotic bacteria to starch granules in microencapsulation technology and for synbiotic food applications such as bakery products.

\section{ACKNOWLEDGEMENT}

We would like to thank Faculty of Science and Technology, Universiti Sains Islam Malaysia for their support.

\section{REFERENCES}

Anal, A.K. and H. Singh, 2007. Recent advances in microencapsulation of probiotics for industrial applications and targeted delivery. Trends Food Sci. Technol., 18: 240-251. DOI: 10.1016/j.tifs.2007.01.004

Bernet, M.F., D. Brassart, J.R. Neeser and A.L. Servin, 1993. Adhesion of human Bifidobacterial strains to cultured human intestinal epithelial cells and inhibition of enteropathogen-cell interactions. Applied Environ. Microbiol., 59: 4121-4128.

Chauviere, G., M.H. Coconnier, S. Kerneis, J. Fourniat and A.L. Servin, 1992. Adhesion of human Lactobacillus acidophilus strain LB to human enterocyte-like Caco-2 cells. Microbiology, 138: 1689-1696. DOI: 10.1099/00221287-138-8-1689

Coconnier, M.H., T.R. Klaenhammer, S. Kerneis, M.F. Bernet and A.L. Servin, 1992. Protein-mediated adhesion of Lactobacillus acidophilus BG2FO4 on human enterocyte and mucus-secreting cell lines in culture. Applied Environ. Microbiol., 58: 20342039. PMID: 1622282

Conway, P.L. and S. Kjelleberg, 1989. Protein-mediated adhesion of Lactobacillus fermentum strain 737 to mouse stomach squamous epithelium. J. Gen. Microbiol., 135: 1175-1186. PMID: 2559944

Corzo, G. and S.E. Gilliland, 1999. Bile salt hydrolase activity of three strains of Lactobacillus acidophilus. J. Dairy Sci., 82: 472-80. PMID: 10194664

Crittenden, R., A. Laitila, P. Forssell, J. Matto and M. Saarela et al., 2001. Adhesion of Bifidobacteria to granular starch and its implications in probiotic technologies. J. Microbiol. Technol., 67: 3469-3475. PMID: 11472921

Cummings, J.H. and G.T. Macfarlane, 1997. Colonic microflora: Nutrition and health. Nutrition, 13: 476478. PMID: 9225346

Fernando, W., S. Flint, S. Charles, K.D.S. Ranaweera and A. Bamunuarachchi, 2011. Environmental factors affecting the adhesion of probiotics to rice fiber fractions. Food Dig., 2: 26-36. DOI: 10.1007/s13228-011-0012-7 
Galdeano, C.M. and G. Perdigon, 2004. Role of viability of probiotic strains in their persistence in the gut and in mucosal immune stimulation. J. Applied Microbiol., 97: 673-681. PMID: 15357716

Hwang, H.I.I., C.H. Lee, S.W. Kim, H.G. Sung and S.S. Lee et al., 2008. Effects of mixtures of Tween 80 and cellulolytic enzymes on nutrient digestion and cellulolytic bacterial adhesion. Asian-Aus. J. Anim. Sci., 21: 1604-1609.

Imam, S.H. and R.E. Harry-O'Kuru, 1991. Adhesion of lactobacillus amylovorus to insoluble and derivatized cornstarch granules. Applied Environ. Microbiol., 57: 1128-1133. PMID: 16348460

Kheadr, E.E., 2006. Impact of acid and oxgall on antibiotic susceptibility of probiotic Lactobacilli. Afr. J. Agric. Res., 1: 172-181.

Kosin, B. and S.K. Rakshit, 2006. Microbial and processing criteria for production of probiotics: A review. Food Technol. Biotechnol., 44: 371-379.

Lee, C.H., H.G. Sung, M. Eslami, S.Y. Lee and J.Y. Song et al., 2007. Effects of Tween 80 pretreatment on dry matter disappearance of rice straw and cellulolytic bacterial adhesion. Asian Aus. J. Anim. Sci., 20: 1397-1401.

Mortazavian, A.M., A. Azizi, M.R. Ehsani, S.H. Razavi and S.M. Mousavi et al., 2008. Survival of encapsulated probiotic bacteria in Iranian yogurt drink (Doogh) after the product exposure to simulated gastrointestinal conditions. Milchwissenschaft, 63: 427-429.

Niderman-Meyer, O., T. Zeidman, E. Shimoni and Y. Kashi, 2009. Mechanisms involved in governing adherence of vibrio cholerae to granular starch. Applied Environ. Microbiol., 76: 1034-1043. DOI: 10.1128/AEM.01533-09
Pongjanta, J., A. Utaipatanacheep, O. Naivikul and K. Piyachomkwan, 2008. Enzymes-Resistant Starch (RS III) from pullulanase- debranched high amylose rice starch. Kasetsart J. Nat. Sci., 42: 198-205.

Pruzzo, C., A. Crippa, S. Bertone, L. Pane and A. Carli, 1996. Attachment of Vibrio alginolyticus to chitin mediated by chitin-binding proteins. Microbiology, 142: 2181-2186. PMID: 8760933

Sajilata, M.G., R.S. Singhal and P.R. Kulkarni, 2006. Resistant starch-a review. Comprehensive Rev. Food Sci. Food Safety, 5: 1-17. DOI: 10.1111/j.1541-4337.2006.tb00076.x

Shah, N.P., 2006. Microorganisms and Health Attributes (Probiotics). In: Manufacturing Yogurt and Fermented Milks, Chandan, R.C. (Ed.), Blackwell Publishing Professional, Iowa, USA., pp: 341-354.

Topping, D.L., 1991. Soluble fiber polysaccharides: Effects on plasma cholesterol and colonic fermentation. Nutr. Rev., 49: 195-203. PMID: 1658695

Wang, L. and Y.J. Wang, 2001. Comparison of protease digestion at neutral $\mathrm{pH}$ with alkaline steeping method for rice starch isolation. Cereal Chem., 78: 690-692. DOI: 10.1094/CCHEM.2001.78.6.690

Wang, X., I.L. Brown, A.J. Evans and P.L. Conway, 1999. The protective effects of high amylose maize (amylomaize) starch granules on the survival of Bifidobacterium spp. in the mouse intestinal tract. J. Applied Microbiol., 87: 631-639. PMID: 10594702

Yavuzdurmaz, H., 2007. Isolation, characterization, determination of probiotic properties of lactic acid bacteria from human milk. Thesis. Izmir Institute of Technology. 